Knox, W. E. (1960b). Pediatrics, Springfield, 26, I.

Lang, K. (1955). Ergebn. inn. Med. Kinderheilk. 6, 78.

Low, N. L., Bosma, J. F. \& Armstrong, M. D. (1957). A.M.A. Arch. Neurol. Psychiat. 77, 359.

Murphy, D. (1959). Irish F. med. Sci. p. 425.

O'Daly, S. (1961). Lancet, i, 1379.

Paine, R. S. \& Hsia, D. Y-Y. (1957). Amer. F. Dis. Child. 94, 224.

Snyderman, S. E., Pratt, E. L., Cheung, M. W., Norton, P., Holt, L. E. Jr., Hansen, A. E. \& Panos, T. (1955), F. Nutr. 56, 253.

Umbarger, B. (1960). Amer. F. Dis. Child. roo, 908.

Waisman, H. A. (I960). In Mental Retardation. Proceedings of the First International Conference on Mental Retardation, p. 3 I9. [P. W. Bowman and H. V. Mautner, editors.] New York: Grune and Stratton Inc.

Waisman, H. A., Wang, H. L., Palmer, G. \& Harlow, H. F. (1960). Nature, Lond., 188, I 124.

Woolf, L. I. \& Edmunds, M. E. (1950). Biochem. 7. 47, 630.

Woolf, L. I., Griffiths, R. \& Moncrieff, A. (1955). Brit. med. $\%$. i, 57.

Woolf, L. I., Griffiths, R., Moncrieff, A., Coates, S. \& Dillistone, F. (1958). Arch. Dis. Childh. 33, 3 I.

Woolf, L. I. \& Vulliamy, D. G. (195I). Arch. Dis. Childh. 26, 487.

\title{
The metabolism of copper and Wilson's disease
}

\section{By J. N. Cumings, Department of Chemical Pathology, The Institute of Neurology, The National Hospital, Queen Square, London, W.C.I}

The use of the word nutrition very frequently conjures up in the mind the idea of many foods composed of carbohydrate, fat or protein. Sometimes thought is given to minerals such as calcium, sodium and potassium but rarely is consideration given to copper, its normal metabolism, and abnormalities that result from alterations in dietary intake of copper.

We all take in the diet and require some $2 \mathrm{mg} \mathrm{Cu}$ /day and in normal subjects there is a fairly accurate degree of balance between intake and output (Cartwright, Hodges, Gubler, Mahoney, Daum, Wintrobe \& Bean, 1954). Occasionally excess $\mathrm{Cu}$ has been taken by mouth, as recorded by Percival ( 1785 ) when a young girl of 17 died from severe intestinal lesions. It would appear to be extremely rare, if not impossible, for man to suffer from a deficient intake, even though a lack of $\mathrm{Cu}$ in cattle (Ryś, 1959), dogs (Van Wyk, Baxter, Akeroyd \& Motulsky, I953), pigs (Lahey, Gubler, Chase, Cartwright \& Wintrobe, 1952; Follis, Bush, Cartwright \& Wintrobe, 1955; Bush, Jensen, Athens, Ashenbrucker, Cartwright $\&$ Wintrobe, 1956) and sheep (Marston, 1952) results in definite abnormalities.

This lack may be because there is insufficient $\mathrm{Cu}$ in the food or because of the presence of other substances in the soil, such as molybdenum which causes an increased $\mathrm{Cu}$ excretion (Dick, $\mathrm{I}$ 953), or because the $\mathrm{Cu}$ is present in possibly a nonavailable form (Pálsson \& Grímsson, I953). In pigs (Gubler, Lahey, Chase, Cartwright \& Wintrobe, 1952) and in rats (Chase, Gubler, Cartwright \& Wintrobe, 1952) lack of $\mathrm{Cu}$ results in anaemia through interference with iron metabolism. Gallagher, Judah \& Rees (1956) have also demonstrated a disturbance of phospholipid synthesis in the $\mathrm{Cu}$-deficient rat. Neither these nor any other manifestations of a deficiency in animals have been found in man. Premature infants with a low dietary $\mathrm{Cu}$ intake of $15 \mu \mathrm{g} / \mathrm{kg}$ daily showed no resulting anaemia or other abnormality (Wilson \& Lahey, r960). 
However, Cu may be regarded as an essential element for certain biochemical processes and in one disease it is present in the body in excessive amounts. It is of interest that there are a number of naturally occurring $\mathrm{Cu}$ proteins as shown in Table $\mathrm{I}$, and that of these seven compounds three can act as enzymes. These seven

Table I. Naturally occurring copper proteins

$\quad$ Cu protein
Caeruloplasmin
Tyrosinase
Cerebrocuprein I
Erythrocuprein
Haemocuprein
Copper protein of liver
Cytochrome C oxidase

$\begin{array}{cc}M & \text { Cu content }(\%) \\ 151000 & 0.34 \\ ? & 0.22-0.25 \\ 30000-40000 & 0.29 \\ 28000 & 0.32-0.36 \\ 35000 & 0.34 \\ 10000 & 0.1-2 \cdot 7 \\ 93000 & 0.07\end{array}$

compounds contain their $\mathrm{Cu}$ bound firmly to the protein, in that it cannot be removed by dialysis or ion exchange columns nor does it react directly with $\mathrm{Cu}$ complexing reagents such as sodium diethyldithiocarbamate. Some of these compounds can be shown to be unique by immunological techniques.

Two enzymes, caeruloplasmin and tyrosinase, have been found to be reduced in amount or absent in some human subjects, and this appears to be inherited in an autosomal recessive manner in the conditions known as hepatolenticular degeneration or Wilson's disease and as albinism.

Wilson's disease is now known to be a condition in which $\mathrm{Cu}$ deposition occurs in the brain, in the liver and in some other organs of the body (Cumings, 1959). It is presumed that the metal acts on the cells, especially those in the brain, either directly as a poison or more probably by an action on cellular enzymes, thereby inhibiting their normal function with resultant death of the cell. Similar effects may occur within the liver where there is a well-marked postnecrotic cirrhosis with fibrosis. Popper (I96I) thinks that the lesion in the liver is directly due to the deposition of the metal.

The abnormalities found in this disease can be briefly mentioned. The tissues as far as is known always contain excess $\mathrm{Cu}$; there is an increased urinary excretion of $\mathrm{Cu}$ of between 100 and $1790 \mu \mathrm{g} / 24 \mathrm{~h}$ compared with a normal level of up to 30 $\mu \mathrm{g} /$ day. The serum $\mathrm{Cu}$ level is almost always reduced; the normal level is $85^{-1}$ Io $\mu \mathrm{g} / \mathrm{r} 00 \mathrm{ml}$ but in this disease it usually lies between 40 and $60 \mu \mathrm{g} / \mathrm{r} 00 \mathrm{ml}$ (Cumings, 1959). There have been on initial examination four exceptions to this finding in forty cases I personally examined. The level of caeruloplasmin, first described by Holmberg \& Laurell (1948), is very significantly reduced and indeed the enzyme is often absent. In the forty cases examined two exceptions to this reduction have been found (see Table 2). There is usually an aminoaciduria in which most amino acids are increased but only rarely is any single one specifically raised in amount.

Table 2. Copper content in body fluids

\begin{tabular}{|c|c|c|c|c|}
\hline & & & Cerebrospinal & Serum caeruloplasmin \\
\hline Condition & $\begin{array}{c}\text { Urine } \\
(\mu \mathrm{g} / 24 \mathrm{~h})\end{array}$ & $\begin{array}{c}\text { Serum } \\
(\mu \mathrm{g} / \mathrm{I} 00 \mathrm{ml})\end{array}$ & $\begin{array}{l}\text { fluid } \\
(\mu \mathrm{g} / 100 \mathrm{ml})\end{array}$ & $\mathrm{mg} / \mathrm{r} 00 \mathrm{ml} \mu \mathrm{l} \mathrm{O} / 2 / \mathrm{ml} \mathrm{h}$ \\
\hline Normal & Up to 30 & $85-110$ & $10-30$ & $100-150$ \\
\hline Wilson's disease & $100-1760$ & $40-60$ & $10-30$ & $0-30$ \\
\hline
\end{tabular}


Normally $\mathrm{Cu}$ is absorbed from the gut by a process whose details are unknown. By means of nuclide studies it has been shown that the absorbed $\mathrm{Cu}$ is attached immediately to albumin, passing within $12-24 \mathrm{~h}$ to an $\alpha_{2}$-globulin to which it becomes firmly attached, and is now the copper protein, caeruloplasmin (Earl, Moulton \& Selverstone, r954; Bearn \& Kunkel, 1954). Excess $\mathrm{Cu}$ is excreted in the faeces, some as a result of non-absorption and some from the biliary system. Small amounts of $\mathrm{Cu}$ are excreted in the urine and some passes to the brain and liver to form the $\mathrm{Cu}$ proteins mentioned in Table $\mathbf{I}$.

It has been suggested that in Wilson's disease there is an increased absorption of $\mathrm{Cu}$ from the gut (Zimdahl, Hyman \& Cook, I953; Wintrobe, Cartwright, Hodges, Gubler, Mahoney, Daum \& Bean, 1954). It is known also that there is an excess of 'direct reacting' $\mathrm{Cu}$ in the blood (Cartwright et al. 1954) which indicates an excess of $\mathrm{Cu}$ loosely bound in albumin.

All these facts suggest that the fault in Wilson's disease lies in the abnormality of caeruloplasmin. Unfortunately it is now realized that the problem is much more complicated, and a few further brief comments on this $\mathrm{Cu}$ protein are necessary. It has been shown by column chromatography that there are present in normal serum two caeruloplasmins (Broman, 1958) and that their relative proportions are different in young infants and in adults (Richterich, 196r). However, such caeruloplasmin as is present in a patient with Wilson's disease appears to be similar electrophoretically to that in a normal subject (Uriel, Götz \& Grabar, 1957). Why a few patients show no abnormality in caeruloplasmin content is quite unknown.

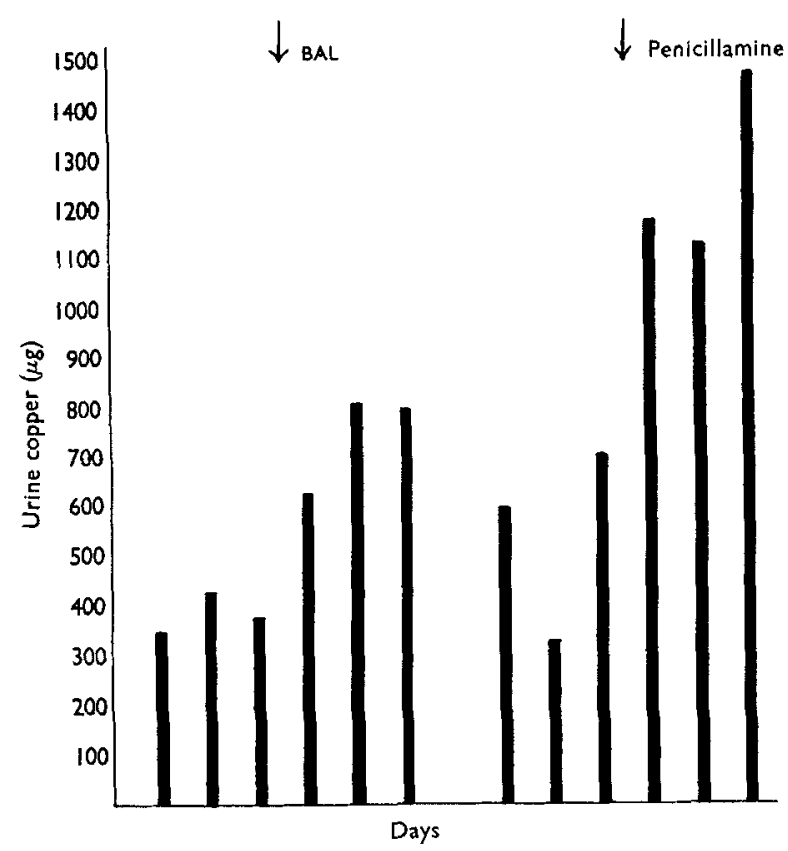

Fig. 1. Effect on the urinary excretion of copper by patients with Wilson's disease of treatment with British Anti-Lewisite (BAL) or penicillamine 
The one certain fact appears to be the increased $\mathrm{Cu}$ deposition in the tissues and such deposition is not found in other conditions. Therapeutic procedures should therefore be such as to encourage the removal of $\mathrm{Cu}$ from the body. One method was suggested by Cumings (1948) and consists in the administration of British AntiLewisite (BAL) in suitable dosage; it liberates $\mathrm{Cu}$ from the tissues which is then excreted (Fig. I).

The second method of value was introduced by Walshe (1956) and consists in the administration of penicillamine by mouth. It produces an even greater excretion of $\mathrm{Cu}$ in the urine than does BAL as can also be seen in Fig. 1. Other methods have been suggested but one or the other of these two together with the administration of potassium sulphide by mouth to prevent absorption of dietary $\mathrm{Cu}$ is the procedure of choice. The results of an investigation into forty cases and the treatment of twentyone patients are illustrated in Table 3 .

Table 3. Investigation of forty patients with Wilson's disease

\begin{tabular}{lr} 
Serum copper abnormal on first examination & 36 \\
Serum oxidase abnormal on first examination & 38 \\
Urine copper abnormal on first examination & 39 \\
Treatment (under personal supervision): by BAL & $\mathbf{2 1}$ \\
\multicolumn{2}{c}{ by penicillamine with or without BAL }
\end{tabular}

Follow-up period: up to 2 years

Initial improvement

Patients died: with neurological improvement

from 2 to 4 years

more than 4 years (one for I I years) after treatment with no treatment

36

38

21

12

9

9

3

19

2

2

Figures are numbers of patients.

What changes take place in the tissues and body fluids as a result of such treatment? They will be mentioned briefly. Two patients who had been treated died and the brain and liver were available for examination. The $\mathrm{Cu}$ contents of these organs were at about normal levels, as can be seen in Table 4 . The serum $\mathrm{Cu}$ and caeruloplasmin levels are rarely altered during treatment. However, changes have been seen

Table 4. Copper content ( $\mathrm{mg} / \mathrm{roO} \mathrm{g} d r \mathrm{y}$ tissue) of the brain and liver of two patients with Wilson's disease after treatment

\begin{tabular}{lrr} 
& \multicolumn{2}{c}{ Patient } \\
\cline { 2 - 3 } \multicolumn{1}{c}{ Tissue } & C.L. & I.G. \\
Liver & 5.6 & $20 \cdot 3$ \\
Basal ganglia & 13.7 & \\
Cerebral white & I2.4 \\
Cerebral cortex & $12 \cdot 4$
\end{tabular}

in two patients and these are illustrated in Fig. 2. One patient showed a slight rise in both $\mathrm{Cu}$ and caeruloplasmin levels and the other patient, in whom the levels of the two substances were originally within normal limits, showed a fall to abnormal concentrations. The urine $\mathrm{Cu}$ content tends to fall during intervals between treatment and there is also a smaller increase during the period of active treatment as 
N.H. 60861

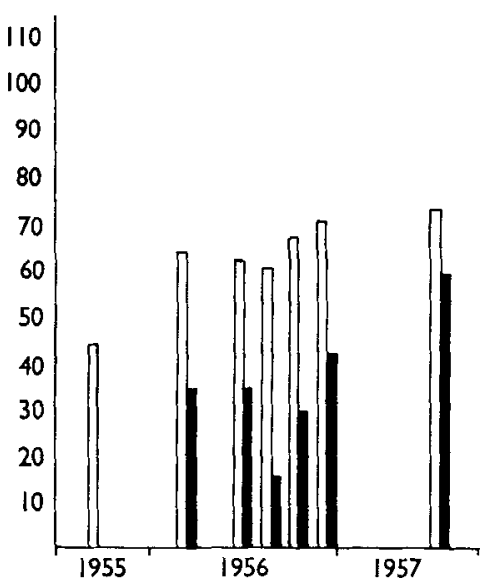

L.S.

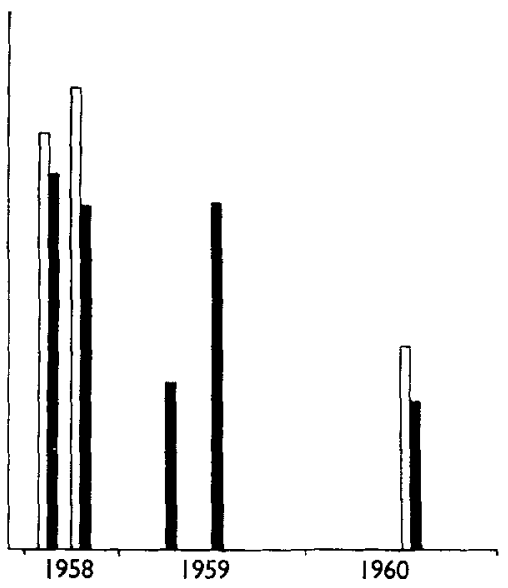

Fig. 2. Effects of treatment with British Anti-Lewisite (BAL) (patient N.H. 6086r, aged ig years) or with penicillamine (patient L.S., aged 14 years) on serum copper and caeruloplasmin of two patients with Wilson's disease. [, copper $(\mu \mathrm{g} / 100 \mathrm{ml}) ;$, copper oxidase $\left(\mu \mathrm{l} \mathrm{O}_{2} / \mathrm{ml} \mathrm{h}\right)$.

compared to the initial periods of treatment. These findings are, of course, compatible with a lowered tissue $\mathrm{Cu}$ level.

Occasionally alterations in calcium metabolism take place during treatment (Playoust \& Dale, 196r). Urinary excretion of calcium is increased but this can be controlled by small doses of cortisone. Bony lesions have also been described in a number of cases (Rosenoer \& Michell, r959).

Many aspects of the metabolism of Cu in Wilson's disease have had to be omitted. One problem that is at present receiving attention is the detection of heterozygotes in families, and another question concerns the actual chemical properties of the enzyme caeruloplasmin. Nevertheless, this relatively rare disease has stimulated a vast amount of basic research which is still being pursued.

\section{REFERENCES}

Bearn, A. G. \& Kunkel, H. G. (1954). Proc. Soc. exp. Biol., N.Y., 85, 44.

Broman, L. (1958). Nature, Lond., 182, I655.

Bush, J. A., Jensen, W. N., Athens, J. W., Ashenbrucker, H., Cartwright, G. E. \& Wintrobe, M. M. (1956). F. exp. Med. ro3, 701.

Cartwright, G. E., Hodges, R. E., Gubler, C. J., Mahoney, J. P., Daum, K., Wintrobe, M. M. \& Bean, W. B. (1954). F. clin. Invest. 33, 1487 .

Chase, M. S., Gubler, C. J., Cartwright, G. E. \& Wintrobe, M. M. (1952). F. biol. Chem. 199, 757.

Cumings, J. N. (1948). Brain, 71, 401.

Cumings, J. N. (1959). Heavy Metals and the Brain. Oxford: Blackwell Scientific Publications.

Dick, A. T. (1953). Nature, Lond., 172, 637.

Earl, C. J., Moulton, M. J. \& Selverstone, B. (1954). Amer. F. Med. 17, 205.

Follis, R. H., Jr., Bush, J. A., Cartwright, G. E. \& Wintrobe, M. M. (1955). Fohns Hopk. Hosp. Bull. 97, 405.

Gallagher, C. H., Judah, J. D. \& Rees, K. R. (1956). Proc. roy. Soc. B, 145, 195.

Gubler, C. J., Lahey, M. E., Chase, M. S., Cartwright, G. E. \& Wintrobe, M. M. (1952). Blood, 7, 1075 .

2I (x) 4 
Holmberg, C. G. \& Laurell, C.-B. (I948). Acta chem. scand. 2, 550.

Lahey, M. E., Gubler, C. J., Chase, M. S., Cartwright, G. E. \& Wintrobe, M. M. (1952). Blood, 7,1053 .

Marston, H. R. (1952). Physiol. Rev. 32, 66.

Pálsson, P. A. \& Grimsson, H. (1953). Proc. Soc. exp. Biol., N.Y., 83, 518.

Percival, T. (1 785$)$. Med. Trans. Coll. Phys. 3, 80.

Playoust, M. R. \& Dale, N. E. (196I). Metabolism, 10, 304.

Popper, H. (1961). In Wilson's Disease: Some Current Concepts, p. 192. [J. M. Walshe and J. N. Cumings, editors.] Oxford: Blackwell Scientific Publications.

Richterich, R. (1961). In Wilson's Disease: Some Current Concepts, p. 81. [J. M. Walshe and J. N. Cumings, editors.] Oxford: Blackwell Scientific Publications.

Rosenoer, V. M. \& Michell, R. C. (I959). Brit. F. Radiol. 32, 805.

Ryś, R. (1959). Nature, Lond., $\mathbf{x 8 3}, 1596$.

Uriel, J., Götz, H. \& Grabar, P. (1957). Schweiz. med. Wschr. Suppl. r4, 43 r.

Van Wyk, J. J., Baxter, J. H., Akeroyd, J. H. \& Motulsky, A. G. (I953). Fohns Hopk. Hosp. Bull. 93, 41.

Walshe, J. M. (1956). Lancet, 270, 25.

Wilson, J. F. \& Iahey, M. E. (1960). Pediatrics, Springfield, 25, 40.

Wintrobe, M. M., Cartwright, G. E., Hodges, R. E., Gubler, C. J., Mahoney, J. P., Daum, K. \& Bean, W. B. (1954). Trans. Ass. Amer. Phycns, 67, 232.

Zimdahl, W. T., Hyman, I. \& Cook, E. D. (1953). Neurology, 3, 569.

\section{Chronic magnesium deficiency}

\section{By Paul Fourman and D. B. Morgan, Medical Unit, Royal Infirmary, Cardiff}

Magnesium deficiency has only rarely been recognized in man and the criteria for its diagnosis are not established (Anonymous, 1960). Most reports so far have been based on the finding of a low serum $\mathrm{Mg}$ content. The patients fall in three groups:

(I) The first includes patients with a low serum $\mathrm{Mg}$ content for which no satisfactory explanation can be produced. Miller (1944) described tetany in a child with a low plasma Mg content. Flink, Stutzman, Anderson, Konig \& Fraser (1954) claimed that $\mathrm{Mg}$ deficiency could complicate chronic alcoholism and even explain delirium tremens. These observations were not satisfactorily controlled (Clough, I960) but recent reports from the same laboratory show that patients with alcoholism, cirrhosis and malnutrition may have a Mg deficiency (McCollister, Flink \& Doe, I960). There is, however, no satisfactory evidence to show that this deficiency produced delirium tremens. Other authors have described patients with an unexplained low serum $\mathrm{Mg}$ content (Hirschfelder \& Haury, I934; Suter \& Klingman, I955; Randall, Rossmeisl \& Bleifer, I 959). More recently it has become obvious that an excessive secretion of aldosterone (Hanna \& MacIntyre, I960) should be considered as a possible factor.

(2) The second group comprises patients who had been losing intestinal fluids while maintained with fluids given parenterally which did not contain $\mathrm{Mg}$. The intestinal secretions normally contain less than 3 m-equiv. $\mathrm{Mg} / \mathrm{l}$. (Nicolaysen, I936), therefore losses must continue for several weeks before a serious deficit can arise (Flink, McCollister, Prasad, Melby \& Doe, I957; Hammarsten \& Smith, 1957; Card \& Marks, I958; Randall et al. I959; Vallee, Wacker \& Ulmer, I960; Baron, I960; Cope \& Barnes, I960).

(3) The third group consists of patients with intestinal malabsorption. Calcium deficiency has long been recognized in steatorrhoea and since the chemical properties of $\mathrm{Mg}$ are very close to those of calcium, steatorrhoea might be expected to produce 